\title{
Where does a volcano break? Using self-potential reiteration to forecast the precise location of major destructive events on active volcanoes: the case study of the Piton de la Fournaise 2007 caldera collapse
}

\author{
Marie Chaput ${ }^{* \alpha, \beta, \gamma}$, Anthony Finizola ${ }^{\alpha, \delta}$, Aline Peltier ${ }^{\delta, \epsilon}$, \\ Nicolas Villeneuve ${ }^{\alpha, \delta, \epsilon}$, Marie Crovisier ${ }^{\alpha}$, Stéphanie Barde-Cabusson ${ }^{\zeta}$ \\ ${ }^{\alpha}$ Université de La Réunion, Laboratoire GéoSciences Réunion, F-97744 Saint Denis, France. \\ $\beta$ Stratagem 974, 62 Boulevard du Chaudron, 97490 Sainte-Clotilde, France.

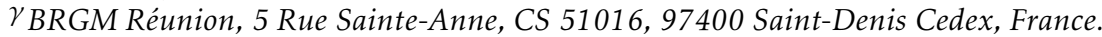

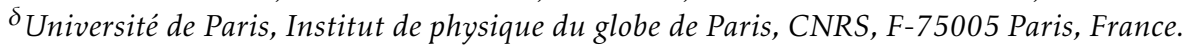 \\ ${ }^{\epsilon}$ Observatoire volcanologique du Piton de la Fournaise, Institut de physique du globe de Paris, F-97418 La Plaine des Cafres, France.

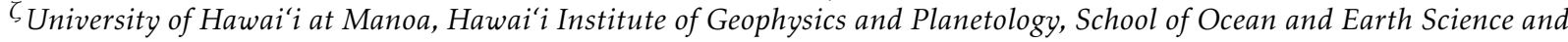 \\ Technology, USA.
}

\begin{abstract}
In April 2007, the Dolomieu caldera collapse was one of the most outstanding events of the last few decades at Piton de la Fournaise volcano. Forecasting the occurrence of such a destructive event is difficult but since then, the development of tools and monitoring networks has improved our knowledge of the dynamics of volcano instability. However, the precise location of volcano failure is still hard to constrain. In this paper, we show that reiteration of self-potential (SP) measurements taken at a one meter step-size along a 440-m-long profile prior to caldera collapse brings valuable insights on the most instable areas around the Dolomieu crater. SP signal dynamic reveals information not visible on one single SP acquisition. In particular, the SP dynamic highlights the presence of low cohesion/low strength materials at depth despite a lack of surface expression. Our survey at Piton de la Fournaise showed that preferential failure area can be precisely identified, at the meter scale. These results highlight the relevance of SP reiteration measurements as a tool for locating instabilities in both volcanic and non-volcanic environments.
\end{abstract}

Keywords: Self-Potential; Piton de la Fournaise volcano; Caldera collapse; Réunion Island

\section{InTRODUCTION}

Summit caldera collapses are common features of basaltic to silicic volcanoes that can occur repeatedly throughout their evolution and are commonly associated with large eruptive crises. Summit calderas are defined as kilometric to pluri-kilometric subcircular depressions formed by the vertical collapse of the summit roof caused by shallow magma reservoir withdrawal during lateral eruptions [Lipman 2000; Kumagai 2001; Cole et al. 2005; Kaneko et al. 2005]. In the past, several caldera collapses have been reported, including Fernandina volcano (Galápagos Islands) in 1968 [e.g. Simkin and Howard 1970], Miyake-jima volcano (Japan) in 2000 [e.g. Geshi et al. 2002], Piton de la Fournaise (La Réunion) in 2007 [e.g. Michon et al. 2007; Staudacher et al. 2009] and more recently Kīlauea (Hawai i) in 2018 [e.g. Neal et al. 2019]. Caldera formation is usually guided by preexisting structures such as ring fault systems and fractures around the summit

*Corresponding author: chaput.marie@orange.fr and can occur as one main collapse event or several incremental collapses [e.g. Piton de la Fournaise Michon et al. 2007]. Due to interaction between hydrothermal and magmatic systems during collapse events, summit caldera formation is often associated with phreatic and phreatomagmatic eruptions that eject tephra and gases up to several hundred to thousand meters high. In inhabited areas, risk assessment related to caldera collapse is therefore of major importance. Yet, occurrence, timing, and magnitude of such events are difficult to constrain and are therefore hardly anticipated. In this paper, we did not focused our survey on the temporal aspect of caldera collapse but on the spatial and geometrical features of such phenomenon. To do this, we used data of a Self-Potential (SP) reiteration profile close to the rim of the summit Dolomieu crater of the Piton de la Fournaise volcano installed before its collapse during the March-April 2007 eruption. The SP method records variations of electrical potential at the subsoil associated with groundwater circulations. High permeability areas (such as fracture systems), constitute preferential pathways for fluids and are commonly 
characterized by low strength, low cohesion material. Our results show that SP mapping combined with SP reiteration can provide valuable information about the structural behavior of calderas and may significantly help in assessing associated hazards. We therefore propose the SP method as a tool for the detection of areas of mechanical weakness on volcanoes, more prone to failure during caldera collapse.

\section{BACKGROUND}

Piton de la Fournaise is a basaltic shield volcano of La Réunion Island, active since at least $540 \mathrm{ka}$ [e.g. Merle et al. 2010]. The summit cone is located within a U-shaped depression, the Enclos Fouqué caldera, opened to the sea toward the east [Merle and Lénat 2003; Oehler et al. 2004; Michon and Saint-Ange 2008]. Most current intrusive activity and eruptions occur within the Enclos Fouqué caldera [e.g. Villeneuve and Bachèlery 2006; Roult et al. 2012]. Three main riftzones are identified: a NE rift-zone coupled with a SE rift-zone centered on the central cone, with outward terminations curved toward the east, and a shorter riftzone axis orientated $\mathrm{N} 120^{\circ} \mathrm{E}$, east of the cone (Figure 1A) [e.g. Bachèlery 1981; Michon et al. 2009]. The summit of the Piton de la Fournaise terminal cone is topped by two craters, the Bory and Dolomieu craters, to the west and east, respectively. Following the summit eruption of August-December 2006, the Dolomieu crater was completely filled in by lavas (Figure 1D). On March 30th, 2007, an eruption started on the SE flank of the volcano, with a first eruptive fissure located at $1900 \mathrm{~m}$ a.s.l. only active for $\sim 10$ hours (Figure 1A). On April 2nd, a second eruptive fissure opened on the lower eastern flank of the volcano, at $600 \mathrm{~m}$ a.s.l. (Figure 1), emitting large volumes of lavas $\left(\sim 164 \mathrm{Mm}^{3}\right.$, ten times larger than a typical Piton de la Fournaise eruption) [Derrien et al. Submitted]. The collapse of the Dolomieu caldera occurred incrementally, mainly between April 5th and 7th, and until April 12th, leading to the formation of a $330 \mathrm{~m}$-deep depression [Michon et al. 2007; Staudacher et al. 2009; Derrien et al. Submitted] (Figure 1E). The magma output at the lateral vent increased during collapse $\left(>200 \mathrm{~m}^{3} \mathrm{~s}^{-1}\right)$ [Staudacher et al. 2009; Fontaine et al. 2019] and the eruption lasted until May 1st. The dimension of the new caldera, 1030 $\times 870 \mathrm{~m}$ [Staudacher et al. 2009], is close to the previous size of the Dolomieu crater, suggesting that the collapse was mostly controlled by a preexisting fault system [Michon et al. 2007].

\section{Self-potential surveys at Piton de la FournaISE}

Self-Potential is a passive method measuring the distribution of natural electrical potential at the ground surface associated with a deep source of current. Various sources can generate a difference of electrical potential but in volcanic environments, the SP signal is related to groundwater flow and mainly generated by the coexistence of two mechanisms: electrokinetic and thermoelectric couplings [Corwin and Hoover 1979; Revil et al. 2003]. Electrokinetic coupling (or streaming potential) results from fluid pressure gradient while thermoelectric coupling results from temperature gradient. Electrokinetic coupling is considered to be the main source of the SP signal on volcanoes since the thermoelectric effect is very low in porous media [Corwin and Hoover 1979]. Under steady state conditions, the groundwater flow itself is controlled by soil permeability, capillary pressure and pressure of the water phase. The SP signal is generally positive in the flow direction so that uprising fluids are commonly associated with positive anomalies [Revil 2002]. SP is thus sensitive to upward or downward fluid flow and permeability changes in the subsoil. It has been used on many volcanoes to constrain the extent of hydrothermal systems and the location of the main structural features draining the fluids [Finizola et al. 2002; Finizola et al. 2004; Revil et al. 2008; Bennati et al. 2011; VillasanteMarcos et al. 2014]. At Piton de la Fournaise, SP studies have been performed in the Enclos Fouqué caldera [Lénat 1987; Malengreau et al. 1994; Zlotnicki 1994] and on the summit cone [Michel and Zlotnicki 1998; Revil et al. 2003; Barde-Cabusson et al. 2012] (Figure 1B). These studies showed the relationship between high SP values and fluid circulation along the rift-zones. They proposed that the Bory and Dolomieu craters constitute the main hydrothermal release; their limits acting as major structural barriers for fluid circulation (Figure 1B). Barde-Cabusson et al. [2012] also identified a hidden preexisting fracture zone in the eastern part of the Dolomieu crater, which probably controlled the first stages of the collapse events in April 2007 (Figure 1B). Summit pit craters (Soufrière pit crater for example; Figure 1B) are also main fluid pathways connected to the central main craters, suggesting possible connections at depth.

\section{Results}

On March 2007, based on the detailed SP mapping performed in July 2006 [Barde-Cabusson et al. 2012], and applying the same strategy of SP reiteration performed on Stromboli volcano before and during the 2002-2003 eruptive crisis [Finizola et al. 2009], we installed a 440$\mathrm{m}$-long SP profile running east-west (Figure 1B, D, E), with benchmarks every meter (Figure 1C), in order to reiterate 440 SP measurements at precisely the same location. The aim to reiterate each SP measurement precisely at the same location is to be exactly influenced by the same rock environment. In that way, the high frequency SP signal, induced by rock heterogeneity, will be exactly the same for two data sets recorded at differ- 

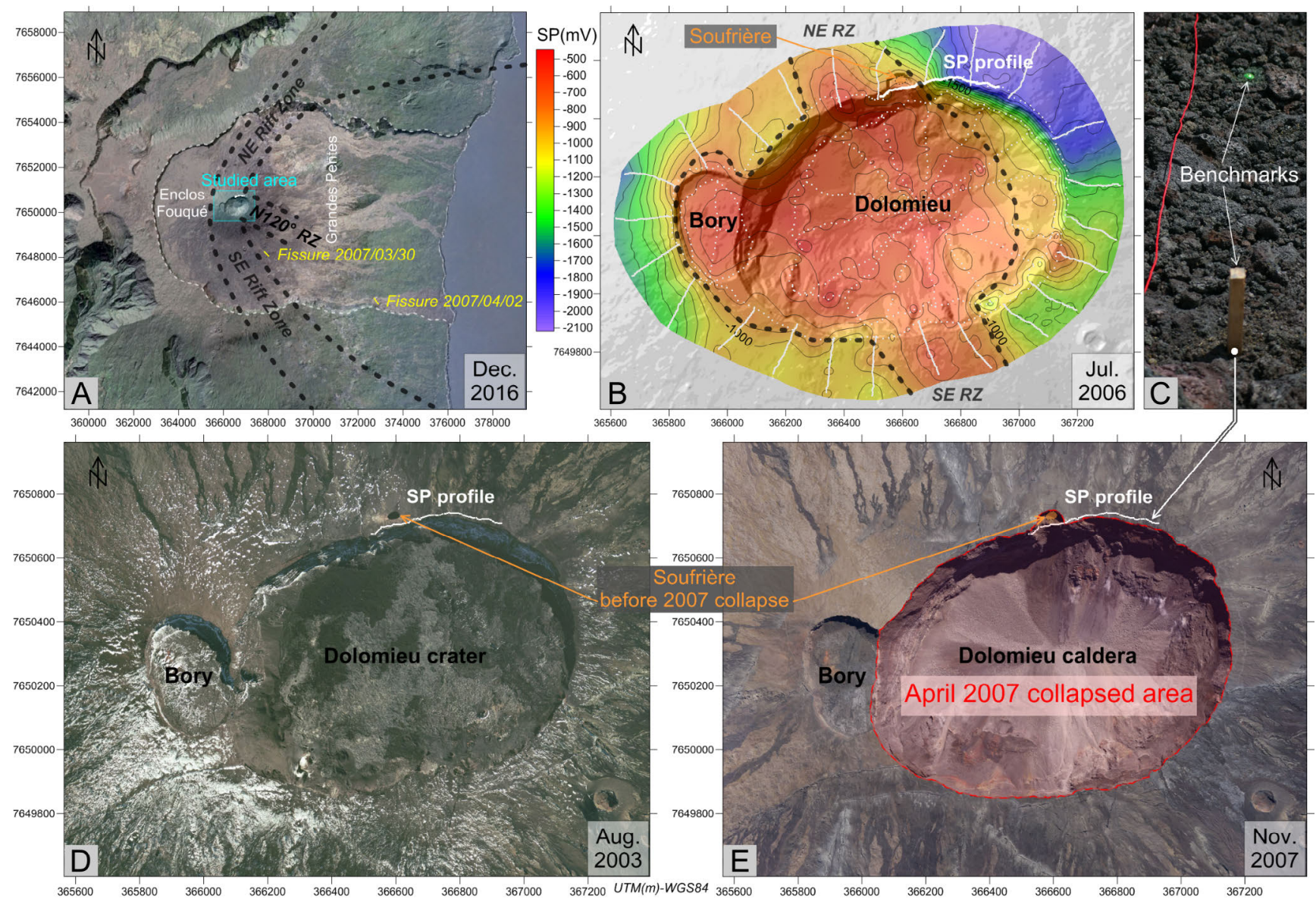

Figure 1: [A] Aerial photograph (Google Earth) of the Piton de la Fournaise volcano superimposed on a digital elevation model, showing the limits of the Enclos Fouqué caldera, the rift-zones and the location of eruptive fissures of March and April 2007. O2019 Google. [B] SP map of the Piton de la Fournaise summit performed in July 2006 (modified after Barde-Cabusson et al. [2012], with permission). Black dashed lines limit the areas of highest SP signal, also corresponding to the borders of craters and rift-zones. The location of the $440 \mathrm{~m}$-long SP profile reiterated during this study is shown (thickest white line). Before collapse, the profile extended between the Soufrière pit-crater and the Dolomieu crater. The $120 \mathrm{~m}$-long western part of the profile collapsed inside the new caldera. $[\mathrm{C}]$ Picture of the benchmarks used in the field to perform precise measurements at the same location for each reiteration. Wood stakes are located every $5 \mathrm{~m}$ and metal spikes are placed every meter. [D] Picture of the Dolomieu crater in August 2003 (photo: E. Cecchi, LMV/OPGC). The location of the Soufrière pit crater, north of Dolomieu, and the location of the $440 \mathrm{~m}$-long SP profile reiterated during this study are shown (white line). [E] Picture of the newly-collapsed Dolomieu caldera in November 2007. The location of the 440-m-long SP profile reiterated during this study is shown (white line) (photo: N. Villeneuve).

ent periods. The location and orientation of this reiteration profile were guided by the highest SP variation identified on the SP map (northern rim of Dolomieu crater) [Barde-Cabusson et al. 2012, Figure 1B]. The SP reiteration profile extended between the Soufrière pit crater and the Dolomieu crater rim, crossing this highest SP anomaly. The reference electrode $\left(\mathrm{e}_{r e f}=0 \mathrm{mV}\right)$ was located in the area of lowest hydrothermal activity (i.e. lower SP values in that case) in the sector, at the eastern end of the profile (point $\mathrm{x}=440 \mathrm{~m}$ ). Each SP measurement records the difference of potential (in $\mathrm{mV}$ ) in the soil with respect to that reference. This area being less vulnerable to variations of SP signal, the temporal evolution of the SP signal in the active hydrother- mal area is more easily identifiable. On volcano flanks, a linear inverse relationship between SP and altitude is commonly observed [Corwin and Hoover 1979; Zlotnicki and Nishida 2003] and is related to purely hydrogeological (as opposed to hydrothermal) zones. However, on active zones of volcanoes, SP tends to increase regardless of altitude variations, in relation with upward hydrothermal fluid flow. Our SP profile is located along the active summit crater of Piton de la Fournaise, and thus recorded SP anomalies marking the activity of the underlying hydrothermal system. Moreover, the altitude variation along the profile is only $17 \mathrm{~m}$, thus the role of elevation on SP signal is negligible.

Self-potential measurements were made every me- 
ter along the profile using a pair of non-polarizable $\mathrm{Cu} / \mathrm{CuSO}_{4}$ electrodes and an insulated copper cable. The difference of electrical potential between the reference electrode and the moving electrode was measured with a high impedance voltmeter. At each station, we dug a small hole (few $\mathrm{cm}$ deep) and sprayed a small quantity of water to improve the electrical contact between the electrode and the ground. Resistance was always measured first, to check the good electrical contact, before acquiring SP data.

The first SP measurements along the profile were made on March 27th 2007, during a ten-day period of progressive increase of the seismicity at Piton de la Fournaise (120 volcano-tectonic earthquakes were recorded on March 27th). SP measurements were reiterated on March 30th, i.e. a few hours before the eruption started (end of measurements at 15h30 UTC, start of seismic crisis at 16h23 UTC, and start of eruption at 18 h50 UTC). Six days after this last survey, the Dolomieu crater started to collapse. From the points 0 to $119 \mathrm{~m}$, the benchmarks of the profile collapsed inside the new caldera; the fault constituting the failure surface was located a few centimeters from $120 \mathrm{~m}$ (precisely at $119.8 \mathrm{~m} \pm 0.1 \mathrm{~m}$ ). The SP signals obtained along the profile on March 27th and March 30th are shown in Figure 2A and display a similar pattern. From west to east, the general SP pattern is first an increase of the signal between 0 and around $85 \mathrm{~m}$ (from +950 to $+1150 \mathrm{mV}$ ), then a decrease of the signal between $85 \mathrm{~m}$ and $380 \mathrm{~m}$ (from +1150 to $-50 \mathrm{mV}$ ), followed by a stabilization of the SP signal between 380 and 440 $\mathrm{m}$ around $0 \mathrm{mV}( \pm 50 \mathrm{mV})$. The maximum SP value was reached at point $84 \mathrm{~m}$ on March $27 \mathrm{th}(\mathrm{SP}=+1116 \mathrm{mV})$ and at point $76 \mathrm{~m}$ on March 30th $(\mathrm{SP}=+1150 \mathrm{mV})$.

This positive SP anomaly corresponds to the eastern side of the NE rift-zone and the evolution of the SP signal from east $(\mathrm{x}=0)$ to west is consistent with the SP map performed in 2006 [Barde-Cabusson et al. 2012], showing a rapid increase of the SP anomaly toward the west (Figure 1B). To highlight the changes in amplitude of the SP signal between March 27th and 30th, we have plotted the SP value difference between the two reiterations in Figure 2B. We applied several running averages (over 3, 5, 7, 9 and 11 points) on the raw data to filter out the high frequency signal associated with small wavelengths. By analyzing the differential between these two datasets using different running averages, we can extract (1) the first order, large wavelength anomaly from the general SP signal, and (2) the high frequency signal from the SP reiteration to evidence the areas mainly affected by highest increase in fluid flow and, by consequence, by higher permeability.

The difference of SP values, $\Delta S P$, between the two profiles shows very small changes in amplitude from points 440 to $140 \mathrm{~m}$. Along these 300 meters, $\triangle \mathrm{SP}$ does not exceed $35 \mathrm{mV}$ for most points. Only a narrow anomaly, $\sim 10 \mathrm{~m}$ large, called anomaly E (i.e. East) is recorded between points 210 and $199 \mathrm{~m}$. Conversely, from points 140 to $0 \mathrm{~m}$, the SP signal shows a significant increase between March 27th and 30th, with two major anomalies, C and $\mathrm{W}$ (i.e. Central and West), and maximum differences of amplitude $\Delta S P$ at points $120 \mathrm{~m}$ and $79 \mathrm{~m}$, respectively (Figure 2B). These maximum $\triangle \mathrm{SP}$ values record the positions where the maximum variation of fluid dynamics occurred between the two dates, corresponding to the areas of maximum ground permeability. The location of these two anomalies is particularly interesting: (1) anomaly W, $40 \mathrm{~m}$ wide, is perfectly correlated to the dimensions of the pre-collapse Soufrière pit crater (Figure 2C) and the highest $\triangle \mathrm{SP}$ value of anomaly $\mathrm{W}$ is located closest to the center of the pre-collapse Soufrière pit crater; (2) the maximum difference in amplitude recorded in the raw data at anomaly $C$ is located at $120 \mathrm{~m}$, i.e. only a few centimeters from the collapsed area (located at $119.8 \mathrm{~m} \pm 0.1 \mathrm{~m}$, Figure $2 \mathrm{~B}, \mathrm{C}$, and Figure $3 \mathrm{~A})$. When looking at the maximum $\triangle \mathrm{SP}$ values obtained after data filtering, these are located between 121 and $125 \mathrm{~m}$, only a few meters from the failure surface.

A close up look of anomaly $C$ shows the presence of two main peaks in the raw data: peak C1 at $120 \mathrm{~m}$ (described above) and a second SP peak, C2, at $127 \mathrm{~m}$ (Figure 3A). In 2009, a major rockfall occurred in the area [Derrien et al. 2018], and once again, the limit of the collapse, located at $125.8 \mathrm{~m} \pm 0.1 \mathrm{~m}$, is $1.2 \mathrm{~m}$ away from the measured $\mathrm{C} 2$ peak (Figure 3B).

\section{Discussion and Conclusions}

Several parameters, both of external and internal origin, can explain the dynamics of SP signal between the two reiterations. External processes mostly involve meteoric water infiltration and recharge of the hydrothermal system while internal processes mostly involve pressurization of the hydrothermal system by deep magma recharge in the plumbing system. Discriminating the implication of these different processes in the SP signal dynamic is difficult and is not the object of this paper. Indeed, whatever the cause of the SP signal dynamic, the most striking feature of these results lies in the spatial relationship between SP signal dynamic and the location of the unstable area along the rim of the Dolomieu crater. During caldera formation, the westernmost part of the SP profile collapsed into the caldera, from points 0 to $119 \mathrm{~m}$. This part of the profile is also the one showing the highest SP anomaly and the largest dynamic. Moreover, the collapse occurred just a few centimeters away from the maximum SP difference $\Delta \mathrm{SP}(\mathrm{x}=120 \mathrm{~m})$. Where no or little SP signal dynamic was recorded, the rim of the Dolomieu crater did not collapse and remained stable over time. A secondary major rockfall occurred in 2009 in this sector and is, again, correlated to a $\triangle \mathrm{SP}$ maximum. SP signal is sensitive to permeability variations at depth. High permeability also suggests the existence of low co- 

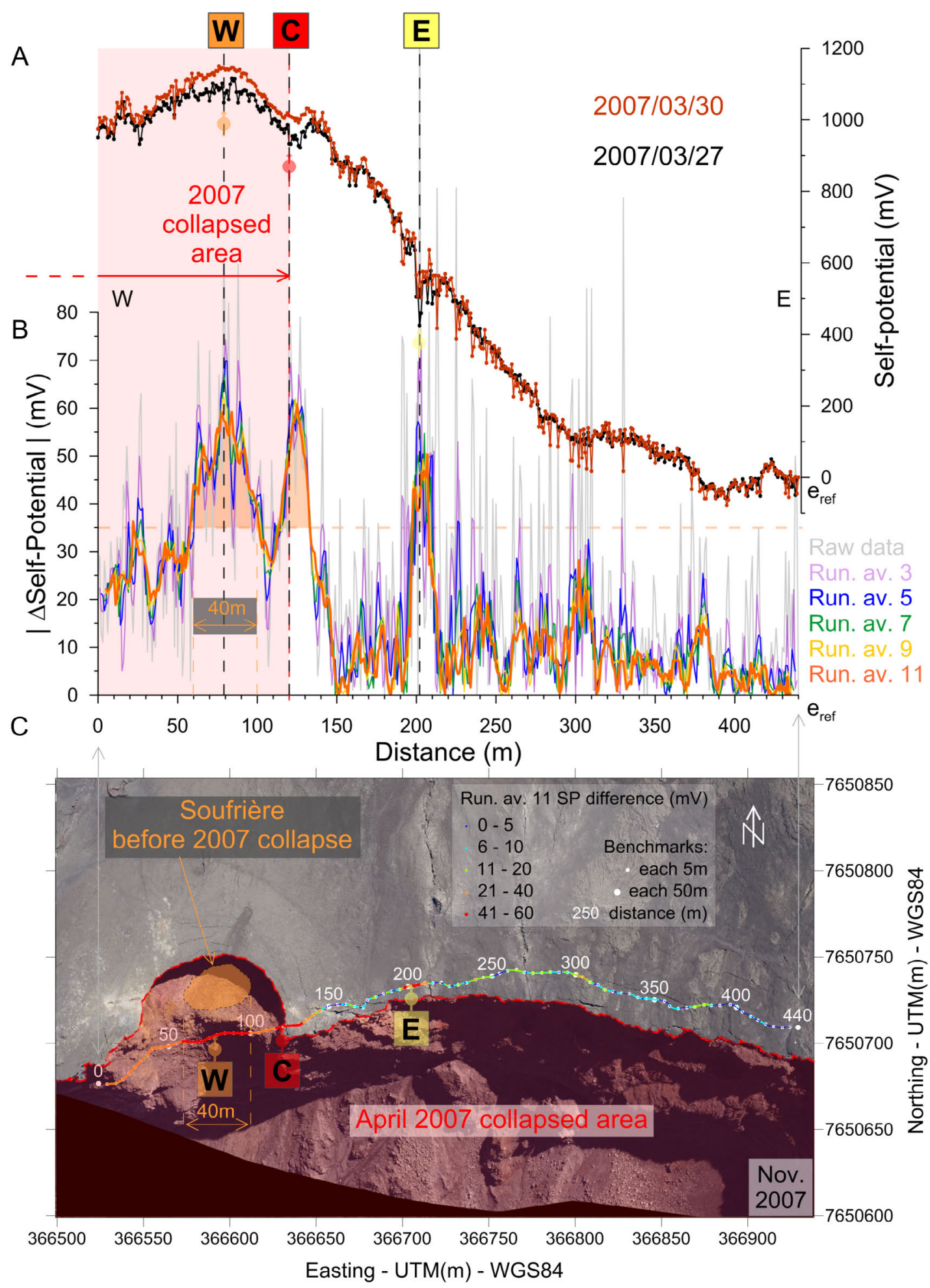

Figure 2: [A] Graphs of the SP signal recorded along the profile on March 27th and 30th. [B] $\Delta$ SP between the two reiterations, showing raw data and filtered data using running averages over 3, 5, 7, 9 and 11 points. [C] Aerial photograph (LGSR) of the studied area taken in November 2007 and showing the collapsed area, the pre-collapse Soufrière pit crater, and the spatial distribution of SP anomalies along the profile. W, C and E stand for western, central and eastern anomalies respectively, and are discussed in the text.

hesion/low strength rocks, probably highly hydrothermally altered in such an active part of the edifice. Because of this mechanical weakness, the host rock is thus more prone to failure and the SP signal dynamic highlights the areas of future collapse.

The origin of the high frequency in the $\Delta \mathrm{SP}$ signal 

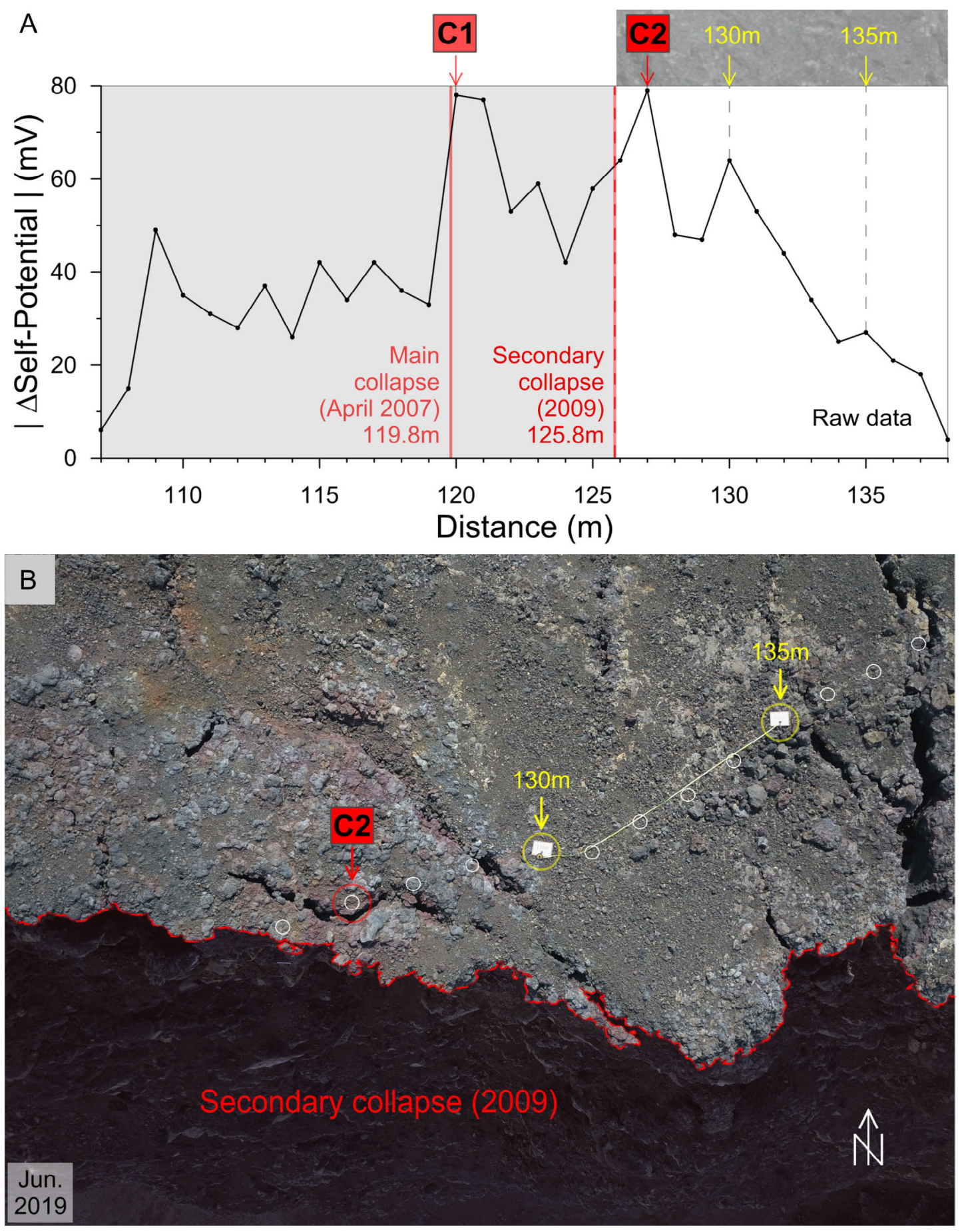

Figure 3: $[\mathrm{A}]$ Graph of the raw $\triangle \mathrm{SP}$ values centered on anomaly $\mathrm{C}$, showing the two peaks, $\mathrm{C} 1$ and $\mathrm{C} 2$, both correlated at the meter scale with collapses of the Dolomieu caldera, in 2007 (main collapse) and in 2009 (secondary major rockfall). [B] Aerial photograph of the study area after the secondary rockfalls, showing the anomaly $\mathrm{C} 2$ at $1.2 \mathrm{~m}$ from the collapsed area (photo: R. Gusset).

recorded between the two campaigns may be the result of large SP differences or $\mathrm{cm}$-scale spatial SP variability. Indeed, as shown by Boudoire et al. [2018], changing the electrode position by a few centimeters between two measurements causes large SP variations related to soil heterogeneities at very small scale. During the March 27th and 30th measurements, the electrode may not have been positioned precisely at the same place near the benchmark, causing most of the recorded high frequency signal. In our case, data filtering allowed us to make the distinction between "real" SP signal dynamic (evidenced by the large wavelength anomalies $\mathrm{E}$, $\mathrm{C}$ and $\mathrm{W}$ ) from high frequency caused by methodological artefacts. A removable mark on the soil near the fixed benchmark (a stone that can be lifted and repositioned for example) would be a simple solution to avoid 
such artefacts in future SP surveys.

One important concern in volcanology is to anticipate both timing and geometry of caldera collapse. Our results highlight the importance of reiterations in SP monitoring for the spatial assessment of caldera collapse. If SP data were recorded only once, the main anomaly $\mathrm{W}$ could have been seen, but anomaly $\mathrm{C}$, which precisely prefigured the location of the collapse, would not have been identified. Are these SP anomalies related to structural features at the surface? SP variations on volcanoes are frequently associated with the presence of eruptive fissures, fractures and faults that concentrate fluid flow. High-resolution aerial photographs of the study area before the 2007 caldera collapse have been analyzed (Supplementary Material 1). They show that, at the emplacement of anomalies $C$ and $\mathrm{W}$, no fracture nor fissure were distinguishable in surface. Currently, it is the same for anomaly E, which is not superimposed on any fracture in surface. Additionally, post-collapse photographs of the cliff just below the post-collapse Soufrière pit crater reveal the presence of reddish, highly weathered materials associated with anomaly C (Supplementary Material 2), precisely where the collapse occurred.

SP monitoring can therefore reveal the presence of high permeability, low cohesion materials at depth, where no geological evidence is noticeable at the surface, and hence provides information about the most unstable areas of the edifice. The consistency between SP dynamics and the collapsed areas highlights the importance of such monitoring method to identify zones of mechanical weakness, independently from the surface fracture network. This method, which can be used in combination with other complementary techniques (e.g. IP surveys, [Revil et al. 2019]) to assess permeability changes, can applied to caldera collapse or flank failure on volcanoes but also to non-volcanic environments, threatened by landslides or any instability phenomena.

\section{Acknowledgements}

Data shown in this paper were collected by Laboratoire GéoSciences Réunion / Université de la Réunion and Observatoire Volcanologique du Piton de la Fournaise, Institut de Physique du Globe de Paris, CNRS. We thank Rachel Mazzucco-Gusset for the June 2019 drone flight and photographies over the Soufriere pit crater. A. Finizola thanks E. Delcher who made the benchmarks. This study contributes to the IdEx Universite de Paris ANR-18-IDEX-0001. This is IPGP contribution number 4064 . Part of this work was also supported by the ANR (Agence Nationale de la Recherche) through the SLIDEVOLC project (contract ANR-16-CE04-004$01)$. The authors thank the two reviewers for their constructive remarks.

\section{Author COnTributions}

M. Chaput undertook the data processing, A. Finizola was in charge of the supervision of the study and installation of the profile, A. Peltier made the DGPS measurements of the benchmarks, N. Villeneuve made the DGPS measurements and the aerial photo processing, M. Croviser made the field work. All authors contributed to writing and discussing the results.

\section{Data AVAil ability}

The data are available in the open access repository Mendeley Data: http://dx.doi.org/10.17632/hbn7hkyc8d.1. Supplementary photographs are available alongside the online version of this article.

\section{COPYRIGHT NOTICE}

(C) The Author(s) 2019. This article is distributed under the terms of the Creative Commons Attribution 4.0 International License, which permits unrestricted use, distribution, and reproduction in any medium, provided you give appropriate credit to the original author(s) and the source, provide a link to the Creative Commons license, and indicate if changes were made.

\section{REFERENCES}

Bachèlery, P. (1981). "Le Piton de la Fournaise, Ile de la Réunion: étude volcanologique, structurale et pétrologique". PhD thesis. University of ClermontFerrand, Clermont-Ferrand, France.

Barde-Cabusson, S., A. Finizola, A. Peltier, M. Chaput, N. Taquet, S. Dumont, Z. Duputel, A. Guy, L. Mathieu, S. Saumet, F. Sorbadère, and M. Vieille (2012). "Structural control of collapse events inferred by self-potential mapping on the Piton de la Fournaise volcano (La Réunion Island)". Journal of Volcanology and Geothermal Research 209-210, pp. 9-18. Dor: 10 . 1016/ j . jvolgeores.2011.09.014.

Bennati, L., A. Finizola, J. A. Walker, D. L. Lopez, I. C. Higuera-Diaz, C. Schütze, F. Barahona, R. Cartagena, V. Conde, R. Funes, and C. Rios (2011). "Fluid circulation in a complex volcano-tectonic setting, inferred from self-potential and soil CO2 flux surveys: The Santa Marı-Cerro Quemado-Zunil volcanoes and Xela caldera (Northwestern Guatemala)". Journal of Volcanology and Geothermal Research 199.3-4, pp. 216-229. Dor: 10.1016/ j . jvolgeores . 2010. 11.008.

Boudoire, G., A. Finizola, A. D. Muro, A. Peltier, M. Liuzzo, F. Grassa, E. Delcher, C. Brunet, P. Boissier, M. Chaput, V. Ferrazzini, and S. Gurrieri (2018). "Smallscale spatial variability of soil CO2 flux: Implication 
for monitoring strategy". Journal of Volcanology and Geothermal Research 366, pp. 13-26. Dor: 10.1016/ j . jvolgeores.2018.10.001.

Cole, J., D. Milner, and K. Spinks (2005). "Calderas and caldera structures: a review". Earth-Science Reviews 69.1-2, pp. 1-26. DoI: 10.1016/ j . earscirev. 2004. 06.004.

Corwin, R. F. and D. B. Hoover (1979). "The selfpotential method in geothermal exploration". Geophysics 44.2, pp. 226-245. DoI: 10.1190/1.1440964.

Derrien, A., A. Peltier, N. Villeneuve, and T. Staudacher (Submitted). "Chronology and volume budget of the 2007 caldera collapse at Piton de la Fournaise: new insights from 4D analysis".

Derrien, A., N. Villeneuve, A. Peltier, and L. Michon (2018). "Multi-temporal airborne structure-frommotion on caldera rim: Hazard, visitor exposure and origins of instabilities at Piton de la Fournaise". Progress in Physical Geography: Earth and Environment 43.2, pp. 193-214. DoI: 10.1177/0309133318808201.

Finizola, A., M. Aubert, A. Revil, C. Schütze, and F. Sortino (2009). "Importance of structural history in the summit area of Stromboli during the 2002-2003 eruptive crisis inferred from temperature, soil CO2, self-potential, and electrical resistivity tomography". Journal of Volcanology and Geothermal Research 183.34, pp. 213-227. Dor: 10 . 1016/ j . jvolgeores . 2009. 04.002.

Finizola, A., J.-F. Lénat, O. Macedo, D. Ramos, J.-C. Thouret, and F. Sortino (2004). "Fluid circulation and structural discontinuities inside Misti volcano (Peru) inferred from self-potential measurements". Journal of Volcanology and Geothermal Research 135.4, pp. 343-360. DoI: 10.1016/ j . jvolgeores.2004.03. 009.

Finizola, A., F. Sortino, J.-F. Lénat, and M. Valenza (2002). "Fluid circulation at Stromboli volcano (Aeolian Islands, Italy) from self-potential and CO2 surveys". Journal of Volcanology and Geothermal Research 116.1-2, pp. 1-18. DoI: 10 . 1016 / s0377-0273 (01) 00327-4.

Fontaine, F. R., G. Roult, B. Hejrani, L. Michon, V. Ferrazzini, G. Barruol, H. Tkalčić, A. D. Muro, A. Peltier, D. Reymond, T. Staudacher, and F. Massin (2019). "Very- and ultra-long-period seismic signals prior to and during caldera formation on La Réunion Island". Scientific Reports 9.1. DOI: 10 . 1038 / s41598- 019 44439-1.

Geshi, N., T. Shimano, T. Chiba, and S. Nakada (2002). "Caldera collapse during the 2000 eruption of Miyakejima Volcano, Japan”. Bulletin of Volcanology 64.1, pp. 55-68. Dor: 10 . 1007 / s00445- 001 $0184-\mathrm{z}$.

Kaneko, T., A. Yasuda, T. Shimano, S. Nakada, T. Fujii, T. Kanazawa, A. Nishizawa, and Y. Matsumoto (2005). "Submarine flank eruption preceding caldera subsidence during the 2000 eruption of Miyakejima Vol- cano, Japan". Bulletin of Volcanology 67.3, pp. 243253. Dor: 10 . 1007/s00445-004-0407-1.

Kumagai, H. (2001). "Very-Long-Period Seismic Signals and Caldera Formation at Miyake Island, Japan”. Science 293.5530, pp. 687-690. DoI: 10.1126/science. 1062136.

Lénat, J.-F. (1987). "Structure et dynamique interne d'un volcan basaltique intraplaque océanique: Le Piton de la Fournaise (île de La Réunion)". PhD thesis. Université Blaise Pascal, Clermont-Ferrand, France.

Lipman, P. (2000). "Calderas". Encyclopedia of volcanoes. Ed. by H. Sigurdsson, B. Houghton, H. Rymer, J. Stix, and S. McNutt. 1st. Academic Press, San Diego, USA.

Malengreau, B., J. Lénat, and A. Bonneville (1994). "Cartography and temporal observation of selfpotential (SP) anomalies at Piton de la Fournaise". Bulletin de la Société Géologique de France 165.3, pp. 221-232.

Merle, O. and J.-F. Lénat (2003). "Hybrid collapse mechanism at Piton de la Fournaise volcano, Reunion Island, Indian Ocean". Journal of Geophysical Research: Solid Earth 108.B3. Dor: 10 . 1029 / 2002 jb002014.

Merle, O., P. Mairine, L. Michon, P. Bachèlery, and M. Smietana (2010). "Calderas, landslides and paleocanyons on Piton de la Fournaise volcano (La Réunion Island, Indian Ocean)". Journal of Volcanology and Geothermal Research 189.1-2, pp. 131-142. DOI: 10.1016/ j . jvolgeores.2009.11.001.

Michel, S. and J. Zlotnicki (1998). "Self-potential and magnetic surveying of La Fournaise volcano (Réunion Island): Correlations with faulting, fluid circulation, and eruption". Journal of Geophysical Research: Solid Earth 103.B8, pp. 17845-17857. Dor: 10.1029/ $98 \mathrm{jb00607.}$

Michon, L., V. Cayol, L. Letourneur, A. Peltier, N. Villeneuve, and T. Staudacher (2009). "Edifice growth, deformation and rift zone development in basaltic setting: Insights from Piton de la Fournaise shield volcano (Réunion Island)". Journal of Volcanology and Geothermal Research 184.1-2, pp. 14-30. DOI: 10 . 1016 / j . jvolgeores. 2008.11.002.

Michon, L. and F. Saint-Ange (2008). "Morphology of Piton de la Fournaise basaltic shield volcano (La Réunion Island): Characterization and implication in the volcano evolution". Journal of Geophysical Research 113.B3. DoI: 10.1029/2005 jb004118.

Michon, L., T. Staudacher, V. Ferrazzini, P. Bachèlery, and J. Marti (2007). "April 2007 collapse of Piton de la Fournaise: A new example of caldera formation". Geophysical Research Letters 34.21. DoI: 10 . 1029 / 2007 gl031248.

Neal, C. A. et al. (2019). "The 2018 rift eruption and summit collapse of Kilauea Volcano". Science 363.6425, pp. 367-374. Dor: 10 . 1126 / science . aav 7046 . 
Oehler, J.-F., P. Labazuy, and J.-F. Lénat (2004). "Recurrence of major flank landslides during the last 2Ma-history of Reunion Island". Bulletin of Volcanology 66.7, pp. 585-598. Dor: 10 . 1007 / s00445- 004 $0341-2$.

Revil, A. (2002). "Comment on "Rapid fluid disruption: A source for self-potential anomalies on volcanoes" by M. J. S. Johnston, J. D. Byerlee, and D. Lockner". Journal of Geophysical Research 107.B8. DoI: 10.1029/ 2001 jb000788.

Revil, A., G. Saracco, and P. Labazuy (2003). "The volcano-electric effect". Journal of Geophysical Research: Solid Earth 108.B5. Dor: 10 . 1029 / 2002 jb001835.

Revil, A. et al. (2008). "Inner structure of La Fossa di Vulcano (Vulcano Island, southern Tyrrhenian Sea, Italy) revealed by high-resolution electric resistivity tomography coupled with self-potential, temperature, and CO2diffuse degassing measurements". Journal of Geophysical Research 113.B7. DoI: 10 . 1029/ 2007 jb005394.

Revil, A., Y. Qi, A. Ghorbani, A. Coperey, A. S. Ahmed, A. Finizola, and T. Ricci (2019). "Induced polarization of volcanic rocks. 3. Imaging clay cap properties in geothermal fields". Geophysical Journal International 218.2, pp. 1398-1427. Dor: 10 . 1093 / g j i / ggz207.

Roult, G., A. Peltier, B. Taisne, T. Staudacher, V. Ferrazzini, and A. D. Muro (2012). "A new comprehensive classification of the Piton de la Fournaise activity spanning the 1985-2010 period. Search and analysis of short-term precursors from a broad-band seismological station". Journal of Volcanology and Geothermal Research 241-242, pp. 78-104. Dor: 10 . 1016 / j . jvolgeores.2012.06.012.
Simkin, T. and K. A. Howard (1970). "Caldera Collapse in the Galapagos Islands, 1968: The largest known collapse since 1912 followed a flank eruption and explosive volcanism within the caldera". Science 169.3944, pp. 429-437. Dor: 10.1126/science. 169. 3944.429.

Staudacher, T., V. Ferrazzini, A. Peltier, P. Kowalski, P. Boissier, P. Catherine, F. Lauret, and F. Massin (2009). "The April 2007 eruption and the Dolomieu crater collapse, two major events at Piton de la Fournaise (La Réunion Island, Indian Ocean)". Journal of Volcanology and Geothermal Research 184.1-2, pp. 126137. Dor: 10.1016/ j . jvolgeores.2008.11.005.

Villasante-Marcos, V. et al. (2014). "Hydrothermal system of Central Tenerife Volcanic Complex, Canary Islands (Spain), inferred from self-potential measurements". Journal of Volcanology and Geothermal Research 272, pp. 59-77. Dor: 10.1016/ j . jvolgeores . 2013. 12.007.

Villeneuve, N. and P. Bachèlery (2006). Revue de la typologie des éruptions au Piton de La Fournaise, processus et risques volcaniques associés. URL: http : / / cybergeo . revues.org/index2536.html (visited on 06/18/2019).

Zlotnicki, J. (1994). "Anomalies de polarisation spontanée et systemes convectifs sur le volcan du Piton de la Fournaise (Ile de la Réunion, France)". Comptes rendus de l'Académie des Sciences. Série IIa: Sciences de la terre et des planètes 318, pp. 1325-1331.

Zlotnicki, J. and Y. Nishida (2003). "Review on Morphological Insights of Self-Potential Anomalies on Volcanoes". Surveys in Geophysics 24.4, pp. 291-338. Dor: 10.1023 /b:geop.0000004188.67923 . ac. 